\title{
A Case of Cervical Mondor's Disease
}

\author{
Yoshiya Ishida $^{122)}$, Tomoaki Sabusawa ${ }^{12)}$, Miki Takaharaa ${ }^{2)}$ and Yasuaki Harabuchi ${ }^{2)}$
}

\begin{abstract}
Mondor's disease is a rare disease characterized by thrombophlebitis of the subcutaneous veins, which mainly occurs in the chest. We report herein on a case of Mondor's disease of the neck. A 30-year-old man complained of a tender mass on his right neck. Physical examination showed folliculitis with a subcutaneous cord-like induration on the neck. Ultrasonographic and CT examinations showed enlargement of a cutaneous vein with a blood clot. The folliculitis and subcutaneous induration disappeared following treatment with oral antibiotics. We thought that the Mondor's disease had developed from the folliculitis. Most of the patients with Mondor's disease recover with conservative treatment within a few months. Therefore, we should bear this disease in mind when we examine patients with painful subcutaneous cord-like indurations on the neck.
\end{abstract}

Keywords : Mondor's disease, neck, man, folliculitis, antibiotics

\section{References}

1) Mondor $\mathrm{H}$ : Tronculite sous-cutané subaigue de la paroi thoracique antero-laterale. Mem Acad Chir (Paris) 65: 1271-1278, 1939.

2）高井良樹，飯野佑一，堀口 淳 : Mondor 病 41 例の検討. Kitakanto Med J 59: 255-258, 2009.

3) Mondor $\mathrm{H}$ and Bertrand I : Thrombophlebitis and periphlebitis of the anterior thoracic wall. Presse Med 59: 1533-1535, 1951.
4) Mera K, Terasaki K, Kanzaki T, et al. : Mondor's disease on the neck. J Dermatol 36: 179-180, 2009.

5）石丸崇史, 堀内賢二, 高田耕基, 他：頸部に生じた Mondor 病の 1 例. 皮膚臨床 43: 1020-1021, 2001.

6）岸㴊正典，弥生恵司，西 敏夫，他：Mondor 病 19 例の検 討. 日臨外会誌 63: 287-290, 2002.

7) Morgan L : Mondor's disease. Med J Aust 2: 379, 1968.

8）一瀬晃洋, 北吉 光, 寺師浩人, 他 : Mondor 病の 6 症例. 日形会誌 22: 510-514, 2002.
1) Department of Otolaryngology, Hokkaido P.W.F.A.C EngaruKosei General Hospital

2) Department of Otolaryngology-Head and Neck Surgery, Asahikawa Medical College
Corresponding Author Address : Yoshiya Ishida amcyoshiyaishida@icloud.com 


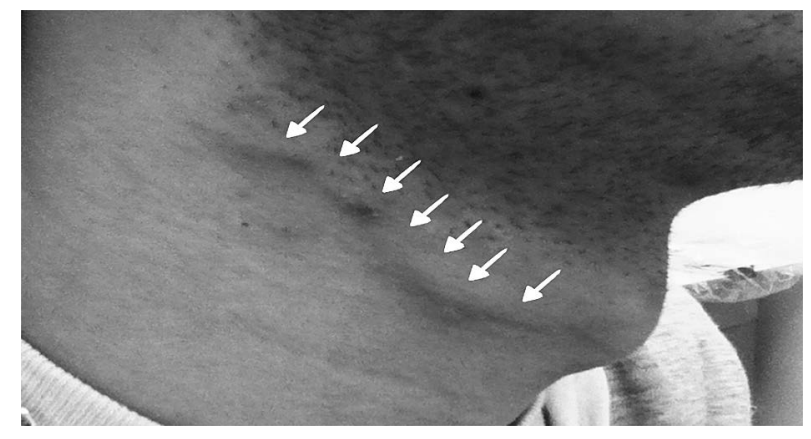

Induration with skin rash is found in the right anterior neck at the first examination. In addition, subcutaneous nodules with cord-like structure are palpable in the anterior neck.

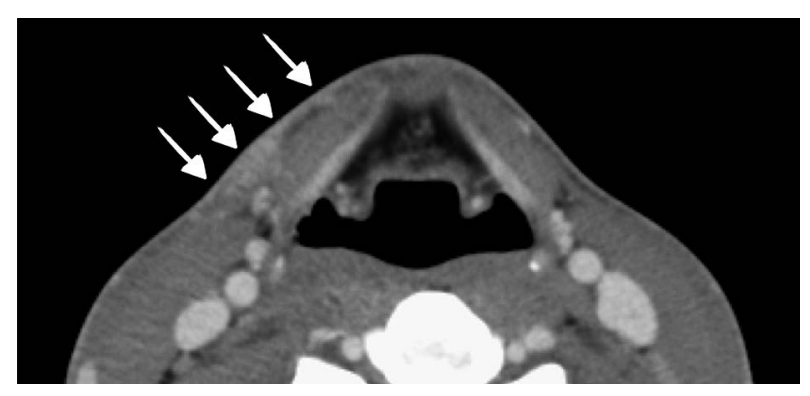

Enhanced CT reveals that the subcutaneous nodules with slight enhancement are arranged in a cord.

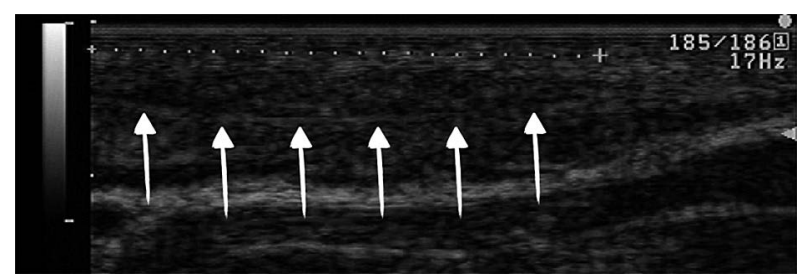

Ultrasonography demonstrates cord-like nodules in the subcutaneous layer, associated with a high-echoic hypertrophic vascular wall as well as a low-echoic lumen (arrows). 